\title{
Consumer behaviour, perceptions, and preferences towards eggs: a review of the literature and discussion of industry implications
}

Article

Accepted Version

Creative Commons: Attribution-Noncommercial-No Derivative Works 4.0

Rondoni, A. ORCID: https://orcid.org/0000-0003-1514-1247, Asioli, D. ORCID: https://orcid.org/0000-0003-2274-8450 and Millan, E. ORCID: https://orcid.org/0000-0002-2421-2855 (2020) Consumer behaviour, perceptions, and preferences towards eggs: a review of the literature and discussion of industry implications. Trends in Food Science \& Technology, 106. pp. 391-401. ISSN 0924-2244 doi:

https://doi.org/10.1016/j.tifs.2020.10.038 Available at https://centaur.reading.ac.uk/93723/

It is advisable to refer to the publisher's version if you intend to cite from the work. See Guidance on citing.

Published version at: http://dx.doi.org/10.1016/j.tifs.2020.10.038

To link to this article DOI: http://dx.doi.org/10.1016/j.tifs.2020.10.038

Publisher: Elsevier

All outputs in CentAUR are protected by Intellectual Property Rights law, including copyright law. Copyright and IPR is retained by the creators or other copyright holders. Terms and conditions for use of this material are defined in 
the End User Agreement.

www.reading.ac.uk/centaur

\section{CentAUR}

Central Archive at the University of Reading

Reading's research outputs online 
Consumer Behaviour, Perceptions, and Preferences towards Eggs:

A Review of the Literature and Discussion of Industry Implications

Agnese Rondoni ${ }^{1, \mathrm{a}}$, Daniele Asioli ${ }^{\mathrm{a}}$, Elena Millan ${ }^{\mathrm{a}}$

${ }^{a}$ Department of Applied Economics and Marketing,

School of Agriculture Policy and Development,

University of Reading, Reading, United Kingdom.

${ }^{1}$ Corresponding author's email address: a.rondoni@pgr.reading.ac.uk 


\begin{abstract}

\section{Background}

During the last decades, several challenges have significantly affected the egg industry, such as the increasing consumer demand for animal welfare, the need for more sustainable food production, and the growing human health and food security issues related to egg consumption. The industry has responded by supplying a large variety of new eggs in the market. A better understanding of consumer behaviour, perceptions, and preferences for eggs is vital for industries to efficiently meet the expected, growing, and complex consumer demand.
\end{abstract}

\title{
Scope and Approach
}

The focus of this review is threefold: (i) to identify the main factors that drive consumer behaviour perceptions, and preferences towards eggs; (ii) to discuss implications for industries and policy makers; and (iii) to identify research gaps to be addressed in future studies. A total of 34 consumer studies were identified, reviewed, and discussed.

\section{Key Findings and Conclusions}

Consumer preferences for eggs are mainly driven by intrinsic and extrinsic characteristics, as well as socio-cultural factors. While price is very important, especially in developing countries, production method in developed countries is a relevant sub-factor, from which consumers make inferences about the health, safety, and sensory properties of eggs. Sensory properties, like eggshell, yolk colours, and size, are also main determinants of egg purchases. Egg producers should better inform consumers about the differences between the various methods of production and the sensory properties of eggs. Finally, this review revealed the need to investigate more factors beyond intrinsic and extrinsic product characteristics as well as the lack of consumer studies in developing countries and on the growing plant-based egg trend. 
Key words: Review; Consumer preferences; Eggs; Industry implications; Policy implications; Future research avenues. 


\section{INTRODUCTION}

Eggs are one of the most important, widespread staple food products around the world, rich in highquality proteins, available at low prices, and consumed on a large scale (Lesnierowski \& Stangierski, 2018). During the last decades, the egg industry has been affected by several critical issues and challenges that have strongly influenced the economics of eggs. First, there are increasing societal concerns towards intensified animal breeding and herding, which are perceived to reduce animal welfare (Malone \& Lusk, 2016; Montossi et al., 2018; Napolitano, Girolami, \& Braghieri, 2010). For example, most of the eggs worldwide are produced using a cage-based system, where hens have very limited space to move and are not allowed to go outside of the hatcheries (Buller \& Roe, 2014), and this poses serious animal welfare concerns. The importance of this issue is signalled by the increasing consumer preference for alternative production systems, causing a shift from conventional battery cage housing systems ${ }^{2}$ (hereafter called caged egg) to cage-free production systems ${ }^{3}$ (hereafter called cagefree egg) (e.g., barn, free-range etc.) (Norwood \& Lusk, 2011a; Parisi, Northcutt, Smith, Steinberg, \& Dawson, 2015; Zakowska-Biemans \& Tekień, 2017). Second, egg production can cause large greenhouse gas (GHG) emissions (Abín, Laca, Laca, \& Díaz, 2018). Indeed, recent data shows that egg production alone is responsible for $9 \%$ of the total emissions of livestock production (FAO, 2016). This is because it relies on a large number of natural resources, such as cereals for feeding the hens, and on high levels of land, water, and energy use (Dekker, de Boer, Vermeij, Aarnink, \& Koerkamp,

\footnotetext{
${ }^{2}$ Battery cage housing systems are indoor-based systems, which typically hold five to ten hens each. The minimum floor space allowance may vary from country to country (e.g., in the United States it is $432.3 \mathrm{~cm}^{2}$ per hen). The water line is located inside the cage and the feeder runs on the outside of the cage front (UEP, 2017).

${ }^{3}$ In cage free production systems, hens are not kept in cages and are free to walk around the houses, to perch on roosts, and to lay eggs in nests (European Commission, 1999). Cage free systems can be barn or aviary, free-range or organic. In barn and aviary systems, hens are given a minimum of $0.09-0.14 \mathrm{~m}^{2}$. The barn system has a section of raised slatted or wire flooring with nest boxes, feeders and nipple drinkers. In the aviary system, the houses are provided with vertical space on which the hens can stand and perch. The laying hens have access to the all house, and they may lay eggs either in the next boxes or on the slatted floor or litter area (UEP, 2017). In free-range systems, hens may be housed within an aviary or barn and are provide with outdoor access via holes in the side of the building (UEP, 2017). Finally, organic systems can be either free-range or pasture based. In order to be certified as organic, the production process has to meet certain requirements such as avoiding the use of antibiotics (UEP, 2017).
} 
2011; Leinonen, Williams, Wiseman, Guy, \& Kyriazakis, 2012). Third, the increasing demand for more extensive egg production systems, including cage-free systems, has also resulted in a higher risk for avian flu outbreaks (Koch \& Elbers, 2006). Indeed, during the last years, several food safety scandals, which caused concerns among consumers, happened in the egg industry, such as the salmonella outbreak in the US in 2015 (Li, Bernard, Johnston, Messer, \& Kaiser, 2017; Whiley \& Ross, 2015) or the egg contamination from Fipronil pesticide in Europe in 2017 (Li et al., 2019). Fourth, there is an increasing number of human health diseases related to the nutritional components of eggs, such as allergies (Loh \& Tang, 2018) and high cholesterol (McNamara, 2015; Zhu, Vanga, Wang, \& Raghavan, 2018), which affect consumer preferences and actual consumption of eggs. Fifth, the continuing growth of the world population is expected to stimulate egg demand ( $+50 \%$ by 2035$)$, which poses serious challenges to increasing egg production in a sustainable manner (FAO, 2017).

These critical issues and challenges, combined with the increasing and complex consumer demand for healthful and sustainable food products (Grunert, Hieke, \& Wills, 2014), have prompted two responses in the egg industry, among others: (i) to introduce into the market a large variety of new eggs, which differ in terms of intrinsic and extrinsic attributes, such as organic, free-range, enriched eggs, etc. (Barnkob, Argyraki, \& Jakobsen, 2020; Surai \& Sparks, 2001) and (ii) to develop new measures to enhance animal welfare standards in egg farms, like, for example, removing the beak trimming practice $^{4}$ (Hester \& Shea-Moore, 2005) or using the innovative dual-purpose poultry system ${ }^{5}$ (Krautwald-Junghanns et al., 2018) as a means to avoid male culling ${ }^{6}$ (Krautwald-Junghanns et al., 2018). Despite the increasing market shift towards new and different types of eggs and the large number

\footnotetext{
${ }^{4}$ The beak trimming consists in removing $1 / 3$ to $1 / 2$ of the beak in order to avoid injuries to other birds in case of cannibalism events or aggressions (Karcher and Mench, 2018).

${ }^{5}$ The dual-purpose poultry is a technique where females are kept producing eggs and males to produce meat with the aim to avoid the so-called 'one-day old chick' practice of culling males' chicken due to their poor meat production and keep only female chicks (Gangnat et al., 2018).

${ }^{6}$ Male culling, also called 'one-day old chick', is related to the practice of culling new born male chickens because of the fact that males cannot lay eggs and poor meat production and therefore only female chicks (Gangnat et al., 2018).
} 
of consumer studies on eggs (Lu, Cranfield, \& Widowski, 2013; Lusk, 2010), there is a lack of clear understanding about how consumers have responded to these changes and how their behaviour, perceptions, and preferences for eggs have evolved during the last years. Shedding light on this topic can guide egg practitioners in developing and marketing new types of eggs and support policy makers' efforts to provide better regulations in line with societal concerns and to understand how to more efficiently inform consumers. Moreover, to the best knowledge of the authors, a coherent overview of the factors that affect consumer behaviour, perceptions, and preferences towards eggs during the last years is missing.

This review aims at filling this void by reviewing and discussing the academic consumer research on eggs from the last ten years aiming to (i) identify the main factors that drive consumer behaviour, perceptions, and preferences for eggs, (ii) discuss implications for egg industries and policy makers, and (iii) identify research gaps to be addressed in future studies.

To conceptualize, identify, and categorize literature findings on consumer behaviour, perceptions, and preferences towards eggs, the present review considers the well-known Mojet's model (Köster, 2009), which identifies the essential categories of factors that influence eating and drinking behaviour and, thus, consumer food choices. This framework has recently been used to synthesize literature findings and describe drivers of food purchases regarding, for example, clean labels (Asioli, Aschemann-Witzel, et al., 2017).

This review is structured as follows. First, a description of the applied methodology used in this study is illustrated together with an overview of the selected studies. Then, the findings of the reviewed studies are structured in accordance with Mojet's model.. Finally, a summary discussion and implications for industries, policy makers, and future research avenues are provided. 


\section{METHODOLOGY}

A literature search was conducted on the following four online catalogues: Scopus, Science Direct, AgEcon Search, and Web of Science. The following keywords or keyword combinations have been searched in the title or abstract: "eggs", AND "consumers" AND "preferences", OR "attitude", OR “perception”, OR “choice”, OR “behaviour”, OR “purchase intention”, OR “willingness to pay”. The review was restricted to English-language, peer reviewed empirical articles examining consumer behaviour, perceptions, attitudes, preferences, and willingness to pay for eggs, published in scientific journals during the last ten years (2010-2019). The decision to limit the search to the last ten years came from the need to offer an overview of the latest studies. Initially, we searched for the same keywords in all four catalogues. A total of 5,030 articles were identified at the first step: 1,866 articles from AgEcon Search, 1,480 articles from Web of Science, 884 articles from Science Direct, and 800 articles from Scopus. Next, the articles not belonging to the agricultural, food, economics, and marketing fields were excluded (4,734). A total of 269 articles were retained at the second step. From these, another 235 studies were excluded either because they were duplications (76) or because their topics were not strictly related to the consumer research subject (159), resulting in a total of 34 articles. The full list of articles included in this review is presented in Table A1 in Appendix A.

The selection process clearly indicates that the number of articles on the reviewed topic has increased during the last ten years, with a notable jump during the last four years, whereas fewer articles were found between 2010 and 2015 (Fig. 1).

\section{[Please insert Fig. 1 here]}

In terms of geographical coverage, the majority of the studies were conducted in developed countries such as the United States (12 articles), Spain (5 articles), Canada (3 articles), Australia (2 articles), the United Kingdom (2 articles), Italy (1 article), Poland (1 article), Norway (1 article), Denmark (1 article), 
and Switzerland (1 article). Fewer articles were found in developing countries, such as Brazil (2 articles), Turkey (1 article), Malaysia ( 1 article), Chile ( 1 article), and Ghana ( 1 article). In terms of research methodologies used in these studies, most articles (29) applied a quantitative approach, mainly using choice experiments or conjoint analysis. Only two of the analysed articles applied a qualitative approach (e.g., focus groups and sentence completion tasks), and two further articles used a mixed methodology including both qualitative and quantitative techniques. Finally, one article used a sensory testing methodology. Regarding their sample size, the quantitative studies varied from a minimum of 74 to a maximum of about 6,378 consumers.

A number of factors that drive consumers' behaviour, perceptions and preferences for eggs were identified and commented on within the literature. In order to have a coherent way of identifying and categorising the factors, we used the well-known model proposed by Mojet (Köster, 2009), which categorize the factors and the sub-factors that influence consumer behavior and food choice (Fig.2).

\section{[Please insert Fig. 2 here]}

\section{RESULTS}

This section provides an overview of the factors driving consumer behaviour, perceptions, and preferences for eggs, examined in the reviewed studies. In line with Mojet's model, all six categories of factors (e.g., intrinsic and extrinsic product characteristics, and socio-cultural, situational, psychological, biological, and physiological factors) were identified. We found varying levels of importance of specific sub-factors, which are reported in Fig. 3. It is relevant to acknowledge that the borderlines between different factors (e.g., between psychological and socio-cultural factors) may be blurred.

\section{[Please insert Fig. 3 here]}


Considering the intrinsic product characteristics, sensory attributes (e.g., size, eggshell colour, appearance, and yolk colour) and nutrient properties (omega-3-enriched) were the most relevant factors affecting consumer behaviour, perceptions, and preferences towards eggs. Concerning size, consumers from Malaysia (Ahmad Hanis, Mad Nasir, Jinap, Alias, \& Ab Karim, 2013), Ghana (AyimAkonor \& Akonor, 2014), and Spain (Baba, Kallas, \& Realini, 2017; Mesías, Martínez-Carrasco, Martínez, \& Gaspar, 2011) showed higher preferences for larger eggs rather than smaller ones. The preference for large eggs may be attributable to the fact that many recipes are made using large size eggs (Ochs, Wolf, Widmar, Bir, \& Lai, 2019). In addition, Ayim-Akonor and Akonor (2014) showed that shoppers from Ghana believed that large eggs are more healthful because they may come from better-fed chickens. With reference to eggshell colour, brown eggs were more liked than white eggs by consumers from Malaysia (Ahmad Hanis et al., 2013), Ghana, Brazil (Ayim-Akonor \& Akonor, 2014), and the United States (Chang, Lusk, \& Norwood, 2010) while Heng, Peterson, \& Li (2013), who conducted a study in the United States, found that consumers showed preferences for white eggs. Eggshell colour preferences may be driven by higher familiarity of consumers with certain types of eggs as well as availability in the markets where they live (Pelletier, 2017). Another important intrinsic attribute is appearance. Wardy, Sae-Eaw, Sriwattana, No, \& Prinyawiwatkul (2015) showed that US consumers do not like visible cracks on the eggshell. Fourth, yolk colour is an important factor which determines product re-purchase (Bray \& Ankeny, 2017). A deep yellow is preferred to a pale yellow coloration by consumers from Ghana (Ayim-Akonor \& Akonor, 2014) and the United States (Heng et al., 2013). Consumer preferences for bright yellow yolk colour emerged, and it can be argued that this may be because brighter colour food is often associated as fresher, more healthful, and safer (Ngapo, Braña Varela, \& Rubio Lozano, 2017). By comparing consumer preferences for yolk colour between omega-3-enriched, free-range, and caged eggs, it emerged that caged-eggs had higher yolk colour acceptance (Baba et al., 2017). Taste, flavour, and odour linked to production methods also emerged as sub-factors that affect consumer preferences for eggs. For example, United Kingdom (Pettersson, 
Weeks, Wilson, \& Nicol, 2016) and Australian consumers (Bray \& Ankeny, 2017) believed that freerange eggs had a better taste than caged eggs because hens are "happier" in free-range based systems than in caged. Baba et al. (2017) found that consumer preferences for flavour were higher for barn and free-range eggs than for omega-3-enriched eggs. In terms of nutrient properties, Heng et al. (2013), Ahmad Hanis et al. (2013), and Mesías et al. (2011) found that US, Malaysian, and Spanish consumers, respectively, were unwilling to pay a premium price for omega-3-enriched eggs. Similarly, Lu, Cranfield, and Widowski (2013) conducted a survey in the United States to investigate consumer preferences for different egg production systems and found that consumers were unwilling to pay a premium price for omega-3-enriched eggs. This may be due to the fact that consumers might have a low grade of familiarity with omega-3-enriched eggs (Baba et al., 2017), or they might have limited knowledge of the benefits of these products (Sass et al., 2018).

Factors of extrinsic product characteristics, like production method, sustainability, price, pack size, freshness, and origin, were found to drive consumer behaviour, perceptions, and preferences towards eggs. Specifically, for production method, consumers prefer cage-free eggs rather than caged eggs. Indeed, consumers from Spain (Lopez-Galan, Gracia, \& Barreiro-Hurle, 2013), the United States (Norwood \& Lusk, 2011a; Ochs et al., 2019), Brazil, Chile (Teixeira, Larraín, \& Hötzel, 2018), and the United Kingdom (Pettersson et al., 2016) showed higher willingness to pay (WTP) for eggs produced in cage-free systems because they are perceived to be produced with higher animal welfare standards (Doyon, Bergeron, Cranfield, Tamini, \& Criner, 2016). In a study carried out in California, Lusk (2010) showed that after the implementation of Proposition $2^{7}$, the demand for cage-free eggs significantly increased compared to the demand in states like Texas, where Proposition 2 was not

\footnotetext{
${ }^{7}$ Proposition 2 stipulated that the minimum cage size needed for chickens to perform particular behaviours (e.g., they must be able "to lie down, stand up, fully extend their legs, and also turn around freely for the majority of the day") (Proposition 2, 2008),
} 
implemented. Interestingly, different findings emerged regarding the preference towards different types of cage-free systems. While consumers from Spain were found to be willing to pay higher prices for free-range eggs rather than organic eggs (Gracia, Barreiro-Hurlé, \& López-Galán, 2014; Rahmani, Kallas, Pappa, \& Gil, 2019), Andersen (2011) found that Danish consumers were willing to pay higher prices for organic rather than barn or free-range eggs. In addition, Guney (2019) showed that Turkish consumers were willing to pay higher prices for organic eggs because they were perceived to be more healthful, more nutritious, and tastier, than caged eggs. In countries like the United States where the egg industry is still mainly based on caged egg systems (Karcher and Mench, 2018), a potential rise in the market share of cage-free eggs is anticipated, although it will likely remain a niche market (Lusk, 2018).

Some studies reported a link between animal welfare and food safety. Consumers perceived that eggs produced by hens raised with higher animal welfare standards were safer to eat (Ochs, Wolf, Widmar, \& Bir, 2018). For example, Li et al. (2017) found that US consumers were willing to pay a premium price for organic eggs after the recall of a half billion eggs in 2010 due to a salmonella outbreak, because they were thought to be safer than caged. Similarly, Taiwanese consumers were found to be willing to pay a higher price for cage-free eggs because they were associated with higher food safety standards (Yang, 2018). Regarding animal welfare, some research investigated consumer preferences for new production method practices providing higher animal welfare standards (Krautwald-Junghanns et al., 2018; Rodenburg et al., 2008). For example, US consumers were willing to pay higher prices for removing the beak trimming practice from production (Ochs et al., 2018). Another study reported that Canadian consumers were willing to pay higher prices for adding further objects in barn systems, such as perches, nesting areas, and scratching pads, to allow more usable space for the hens (Doyon et al., 2016). Gangnat et al. (2018) revealed that Danish consumers were willing to pay higher prices for eggs if the practice of dual-purpose poultry was applied in production. Regarding other extrinsic characteristics like sustainability, evidence suggests that Brazilian and Chilean consumers were 
unwilling to pay a premium price for sustainable eggs, produced with reduced amounts of water and higher standards of manure treatment (Teixeira et al., 2018). Similarly, Spanish consumers were found to be unwilling to pay a premium price for eggs claimed to be produced with reduced greenhouse gas (GHG) emissions and water use (Rahmani et al., 2019). On the other hand, US consumers were willing to pay a premium price for organic-fed and vegetarian-fed eggs, which have a lower impact on the environment (Heng et al., 2013). Price was the most important factor for consumers when purchasing eggs from Malaysia (Ahmad Hanis et al., 2013), Ghana (Ayim-Akonor \& Akonor, 2014), Spain (Baba et al., 2017), Poland (Zakowska-Biemans \& Tekień, 2017), and Canada (Allender \& Richards, 2010). In terms of pack size, Ahmad Hanis et al. (2013) reported that Malaysian consumers prefer larger pack sizes (e.g., ten to thirty eggs per pack) to smaller (e.g., six or less than six eggs per pack), because of the lower price per egg. Freshness was particularly important for US consumers who indicated shelf life as the most salient attribute for them when they buy eggs (Wardy et al., 2015). Concerning origin, consumers from Spain showed a stronger preference and higher willingness to pay for locally-produced than imported eggs (Baba et al., 2017; Gracia et al., 2014; Lopez-Galan et al., 2013).

The socio-cultural factors of income, food habits, usage, educational level, attitudes, and trust in the certification institution were found to significantly affect consumer behaviour, perception, preferences, and willingness to pay for eggs. As for income, some contradictory findings were reported. While Andersen (2011) found that higher-income Danish shoppers were willing to pay a higher price for freerange and organic eggs, and Yang (2018) reported that higher-income Taiwanese consumers were willing to pay higher prices for barn and free-range eggs, Vecchio \& Annunziata (2012) found that higher-income Italian consumers were not willing to pay higher prices for free-range eggs. Surprisingly, differences between the reported willingness to pay among households with different incomes in the United States were found not to significantly affect consumer purchase behaviour for eggs (Spain, Freund, Mohan-Gibbons, Meadow, \& Beacham, 2018). Food purchasing habits can affect consumers purchases of eggs. For example Gerini, Alfnes, \& Schjøll (2016) found that Norwegian consumers who 
usually buy organic food tend to buy more organic eggs than those who only sometimes buy organic food. Interestingly, egg purchasing was found to be driven also by the use that consumers make of them and how many they need. For example, if eggs are purchased for baking, United Kingdom consumers are likely to prefer caged eggs, whereas in recipes where eggs are the main ingredient (e.g., omelettes, hard-boiled eggs, etc.), they would more likely use free-range eggs and would also be willing to pay a premium price for them (Pettersson et al., 2016). Concerning education, more highly educated Taiwanese consumers were found to be willing to pay higher prices for eggs with animal welfare information than those with a lower educational level (Yang, 2018). In Canada, consumers with a higher educational level and income were found to prefer free-range eggs, whereas those with a lower educational level and income preferred white eggs (Bejaei, Wiseman, \& Cheng, 2011). Consumer attitudes, such as pro-animal welfare and pro-environmental attitudes, also affect consumer purchasing behaviour and willingness to pay for eggs. With respect to pro-animal welfare attitudes, Spanish (Lopez-Galan et al., 2013), US (Norwood \& Lusk, 2011b; Spain et al., 2018), Brazilian, Chilean (Teixeira et al., 2018), and United Kingdom consumers (Bennett, Jones, Nicol, Tranter, \& Weeks, 2016) who expressed concern for animal welfare conditions on farms also showed higher willingness to pay for cage-free eggs. Conversely, Vecchio \& Annunziata (2012) showed that although Italian consumers expressed concern for animal welfare standards, they rarely purchased cage-free eggs. Consumers' pro-environmental attitudes were found to positively affect shoppers' willingness to pay for free-range and organic eggs in Spain (Andersen, 2011), but this did not necessarily translate into willingness to pay a higher price for eco-friendly produced eggs (Teixeira et al., 2018). Last, trust in the certification institution is an important sub-factor. Indeed, consumers' willingness to pay for eggs with enhanced animal welfare standards (e.g., free-range and organic) in the United Kingdom (Bennett et al., 2016) and in the United States (Spain et al., 2018) increased only if the animal welfare label was accredited by an external third-party institution or by the federal government. 
Among the psychological factors, lack of knowledge and health-related beliefs were found to affect consumer purchases of eggs. Güney \& Giraldo (2019) revealed that Turkish consumers were reluctant to purchase organic eggs because they do not know the characteristics of organic egg production. This may be because consumers still may not be aware of the differences between the different production systems. Similarly, Vecchio \& Annunziata (2012) showed that consumers were unaware of the meaning of the current labelling system for eggs. This also emerged in Pettersson et al. (2016), who compared the understanding of consumers and experts towards animal welfare in the context of egg production and found that both believed that "space allowance" was the major benefit in free-range production; however, "giving access to the outside," "fresh air," and "giving access to the sunlight" were rated low by the experts and very high by consumers. Also, other practices used in egg production were still largely unknown by consumers as shown by Gangnat et al. (2018), who found that only 17\% of the Swiss respondents indicated they knew about male chick culling and dual-purpose poultry practices. In terms of health-related beliefs, consumers from Ghana preferred brown eggs to white because they were thought to be more healthful and to contain a lower cholesterol ratio (Ayim-Akonor \& Akonor, 2014). Bray \& Ankeny (2017) conducted a qualitative study with Australian consumers and found that consumers believed that cage-free eggs are more healthful than caged eggs because of the healthier diet that hens are believed to follow in cage-free systems (e.g., free from "chemicals," hormones, and added antibiotics).

Among the biological and physiological factors, gender and age have been found to influence consumer preferences for eggs. British women tend to buy more free-range eggs than other types of cage-free or caged eggs than men (Pettersson et al., 2016). This is in line with past research that showed that women generally give more importance to animal welfare than men (Vanhonacker, van Poucke, Tuyttens, \& Verbeke, 2010). From an investigation carried out by Rahmani et al. (2019), it emerged that young Spanish consumers (e.g., less than 40 years) were willing to pay higher prices for free-range and organic eggs than caged-eggs. In contrast, older (e.g., older than 40 years) Danish (Andersen, 2011) 
and Taiwanese consumers (Yang, 2018) were willing to pay higher prices for free-range and organic eggs, and this can be explained by the fact that older people may have higher income than younger consumers.

Finally, the situational (i.e., contextual) factors of living area and availability have been found to affect consumer preferences for eggs. With regard to living area, Andersen (2011) conducted a study in Denmark and found that shoppers from urbanized areas were willing to pay higher prices for cagefree eggs than caged eggs. Furthermore, availability of different egg types in stores was found to negatively influence consumer preferences in some countries. For example, Turkish consumers were sceptical to buy organic eggs because they were not used to them due to the scarce availability in shops and retail markets (Güney \& Giraldo, 2019).

\section{DISCUSSION \& CONCLUSIONS}

The following discussion is structured according to the objectives guiding this review, and, thus, it first summarizes the factors influencing consumer behaviour and preferences for eggs, follows up with a discussion of the implications for egg industries and policy makers, and concludes with an analysis of the research gaps that emerged from the review possibly to be addressed in future studies.

\subsection{Consumer behaviour, perceptions, and preferences for eggs}

Based on the outcomes that emerged from this review, several considerations can be derived. First, although eggs are one of the most popular and widely consumed staple foods around the world, relatively few studies have investigated consumer behaviour, perceptions, and preferences towards eggs. Also, most of them are concentrated in developed countries, especially the United States. Second, based on Mojet's model (Köster, 2009), intrinsic, extrinsic, socio-cultural, situational, biological, and physiological factors affect consumer behaviour, perceptions, and preferences towards eggs. Thus, we 
can conclude that a large variety of drivers have been found to affect consumer behaviour, perceptions, and preferences towards eggs, according to the empirical consumer studies from the past ten years. Third, it seems that product characteristics (e.g., intrinsic and extrinsic) are the most investigated factors that affect consumer preferences for eggs. Specifically, production method and sensory attributes are relevant sub-factors in affecting consumer preferences for eggs, particularly in North and South America as well as in European countries. Interestingly, several studies showed that there is a complex consumer-perceived interaction between production method and other product attributes. Specifically, consumers perceive that production method may affect the healthfulness, food safety, and sensory properties of eggs. Concerning sensory attributes, eggshell and yolk colours, appearance, and taste are relevant factors affecting consumer behaviour, perceptions, and preferences for eggs. These findings are corroborated by a large number of studies that indicate sensory attributes are influencing factors affecting consumer food choices (De Pelsmaeker, Dewettinck, \& Gellynck, 2013; Grunert, 2005). Interestingly, while in developed countries a heterogeneous preference between brown and white eggshells emerged, in developing countries consumers prefer brown eggshells. Fourth, in terms of socio-demographic characteristics, those with higher income, the young, females, and educated consumers prefer cage-free eggs and are willing to pay higher prices for them. Fifth, a few studies have investigated the environmental sustainability issues, in terms of reduced greenhouse gas (GHG) emission and water use; these showed that consumers do not pay much attention to this element when purchasing eggs. Sixth, price has been found to be a key determinant for egg purchases, especially in developing countries. Finally, consumer habits and attitudes toward sustainability, health, and animal welfare may affect consumer behaviour, perceptions, and preferences towards eggs.

\subsection{Implications for food producers and policy makers}

Several implications for egg producers can be derived from the outcomes of this review. First, egg producers should expect that a diversity of factors impact egg purchasing and, thus, need to be prepared 
to take the diversity of these drivers into account in developing new types of eggs. Specifically, intrinsic and extrinsic product characteristics as well as socio-cultural factors influence consumer preferences for eggs significantly, while less can be concluded or known for the remaining factors. Second, in developed countries, the production method is a crucial attribute that drives consumers when they purchase eggs, partly because consumers infer healthfulness, food safety, and sensory properties of eggs from the type of production method. Thus, it is important that egg producers communicate to consumers the benefits of higher animal welfare standards through labelling and the effect that the production method has on healthfulness, food safety, and sensory properties of the products, if any, for marketing and transparency purposes. Third, it looks like those with higher income, the young, females, and educated consumers are more attracted to cage-free eggs and might be the segment of consumers to launch the cage-free egg market. Fourth, in terms of sensory attributes, eggshell colour and yolk appearance emerged as key sensory attributes together with the size of the eggs, which food producers should consider when marketing eggs. Therefore, a better communication of sensory attributes on the label would help consumers to find the type of eggs that they wish to buy, for example, by indicating on the label the colour of the yolk. Lastly, price seems to be a key driver for egg purchasing, especially in developing countries, which should be considered in the marketing strategies to lower the prices of eggs in those markets.

For policy makers interacting with egg producers, production method and sensory attributes are major drivers, which suggest that they need to consider how to ensure that consumers are not misled by information about these factors in any way. Specifically, it would be very important that policy makers are able to better regulate the production method by informing consumers about the different types of cage-free eggs, supporting, for example, the adoption of standards and certifications so that consumers can make more informed choices using independent third party certification (Yang, 2018). Similarly, as consumers are still unwilling to pay more for omega-3 enriched eggs, as well as for eggs produced with reduced GHG emissions, policy makers should work with producers to better inform consumers 
about the health and environmental benefits that can be derived from purchasing these eggs. Finally, policy makers should also aim to support measures that allow a reduction of prices for eggs in developing countries, in order to allow all consumers to afford to purchase eggs.

\subsection{Future research directions}

This review has brought forth several questions in need of further investigation. First, future studies should ascertain more clearly the influence of the production method on consumer-perceived health and sensory benefits and potential food safety risks both from food science and marketing sides. Second, it would be interesting to establish how egg preferences differ across diverse consumer groups. In addition, future studies, similar to the work done by Lusk (2018), can try to estimate the market for cage-free eggs in different countries. Third, most of the existing consumer studies on eggs are from developed countries. Our findings indicate some cultural variations in egg preferences and consumption. Therefore, research on consumer behaviour, perceptions, and preferences for eggs in emerging markets will broaden our understanding of this subject. Fourth, further research needs to be undertaken to better investigate the behavioural drivers of consumer decision making for eggs. For instance, future studies could use structural equation modelling (SEM) to investigate the strength of the effects of the factors identified in this paper for egg products to better understand how they contribute to consumer choice decisions. Fifth, it would be interesting to establish whether the inclusion of various psychological factors (e.g., risk preferences, time preferences, and personality, among others) into economic models of consumer demand could improve their predictive power and, thus, help to better understand consumer decision making processes for egg products. Sixth, further experimental investigations are needed to explore how consumers value the sensory aspects of eggs by using different consumer valuation methods, such as experimental auctions or real choice experiments as proposed by Asioli, Varela, et al. (2017). Seventh, new technologies aiming to enhance animal welfare standards in the egg industry have been recently developed, such as a system for detecting the in-ovo 
gender of chicks ${ }^{8}$. However, since the adoption of these new practices could be very expensive for egg producers, research should be conducted to estimate consumer willingness to pay for eggs produced with these new technologies to compare with costs of production in order evaluate the economic sustainability for producers. In terms of eco-sustainability, a new frontier of feeding systems is driving towards insect-based feed (Borrelli et al., 2017). Thus, future studies should investigate the effect of insect-fed both on nutritional and sensory properties, as well as consumer preferences for this type of eggs. Eight, there is a need to conduct more research to improve the sensory and nutritional properties of eggs able to develop new egg products that better meet consumers' needs and wishes, for example enriched eggs (Barnkob et al., 2020). Finally, there has been a recent increase of interest in plant-based $\operatorname{eggs}^{9}$ in the global market. Thus, it would be important to conduct research on product development and consumer preferences for plant-based eggs in order to provide useful information for plant-based egg producers and policy makers with evidence on this new trend.

\section{ACKNOWLEDGEMENTS}

This research did not receive any specific grant from funding agencies in the public, commercial, or not-for-profit sectors.

\section{REFERENCES}

Abín, R., Laca, A., Laca, A., \& Díaz, M. (2018). Environmental assesment of intensive egg production: A Spanish case study. Journal of Cleaner Production, 179, 160-168.

Ahmad Hanis, I. A. H., Mad Nasir, S., Jinap, S., Alias, R., \& Ab Karim, M. S. (2013). Consumer's

\footnotetext{
${ }^{8}$ One of these systems use radioimmunoassay (RIA) technology to determine embryos gender (Tran, Ferrell, \& Butt, 2010); others have checked for estrone sulphate which is higher in females and identified gender with an accuracy of $84 \%$ for 8 days of incubation and of 98\%-100\% for 9 days (Weissmann, Reitemeier, Hahn, Gottschalk, \& Einspanier, 2013).

${ }^{9}$ Plant-based egg has been developed either through protein isolation or protein fermentation. The protein fermentation method follows an acellular production, where protein and fats components in eggs can be re-produced through a process of fermentation of microbes like yeast or algae (Geng, Song, Qi, \& Cui, 2011).
} 
preferences for eggs attributes in Malaysia: Evidence from conjoint survey. International Food Research Journal, 20(5), 2865-2872.

Allender, W. J., \& Richards, T. J. (2010). Consumer impact of animal welfare regulation in the California poultry industry. Journal of Agricultural and Resource Economics, 35(3), 424-442.

Andersen, L. M. (2011). Animal welfare and eggs - Cheap talk or money on the counter? Journal of Agricultural Economics, 62(3), 565-584.

Asioli, D., Aschemann-Witzel, J., Caputo, V., Vecchio, R., Annunziata, A., Næs, T., \& Varela, P. (2017). Making sense of the "clean label" trends: A review of consumer food choice behavior and discussion of industry implications. Food Research International, 99, 58-71.

Asioli, D., Varela, P., Hersleth, M., Almli, V. L., Olsen, N. V., \& Næs, T. (2017). A discussion of recent methodologies for combining sensory and extrinsic product properties in consumer studies. Food Quality and Preference, 56, 266-273.

Ayim-Akonor, M., \& Akonor, P. T. (2014). Egg consumption: Patterns, preferences and perceptions among consumers in Accra metropolitan area. International Food Research Journal, 21(4), 14571463.

Baba, Y., Kallas, Z., \& Realini, C. (2017). Application of the analytical hierarchy process to evaluate consumer acceptance and preferences for omega-3 enriched eggs. British Food Journal, 119(7), $1459-1472$.

Barnkob, L. L., Argyraki, A., \& Jakobsen, J. (2020). Naturally enhanced eggs as a source of vitamin D: A review. Trends in Food Science \& Technology.

Bejaei, M., Wiseman, K., \& Cheng, K. M. (2011). Influences of demographic characteristics, attitudes, and preferences of consumers on table egg consumption in British Columbia, Canada. Poultry Science, 90(5), 1088-1095.

Bennett, R. M., Jones, P. J., Nicol, C. J., Tranter, R. B., \& Weeks, C. A. (2016). Consumer attitudes to injurious pecking in free-range egg production. Animal Welfare, pp. 91-100.

Borrelli, L., Coretti, L., Dipineto, L., Bovera, F., Menna, F., Chiariotti, L., Fioretti, A. (2017). Insect- 
based diet, a promising nutritional source, modulates gut microbiota composition and SCFAs production in laying hens. Scientific Reports, 7(1), 1-11.

Bray, H. J., \& Ankeny, R. A. (2017). Happy Chickens Lay Tastier Eggs: Motivations for Buying Freerange Eggs in Australia. Anthrozoos, 30(2), 213-226.

Buller, H., \& Roe, E. (2014). Modifying and commodifying farm animal welfare: The economisation of layer chickens. Journal of Rural Studies, 33, 141-149.

Chang, J. B., Lusk, J. L., \& Norwood, F. B. (2010). The price of happy hens: A hedonic analysis of retail egg prices. Journal of Agricultural and Resource Economics, 35(3), 406-423.

De Pelsmaeker, S., Dewettinck, K., \& Gellynck, X. (2013). The possibility of using tasting as a presentation method for sensory stimuli in conjoint analysis. Trends in Food Science \& Technology, 29(2), 108-115.

Dekker, S. E. M., de Boer, I. J. M., Vermeij, I., Aarnink, A. J. A., \& Koerkamp, P. W. G. G. (2011). Ecological and economic evaluation of Dutch egg production systems. Livestock Science, 139(12), 109-121.

Doyon, M., Bergeron, S., Cranfield, J., Tamini, L., \& Criner, G. (2016). Consumer Preferences for Improved Hen Housing: Is a Cage a Cage? Canadian Journal of Agricultural Economics, 739751.

European Commission. (1999). Protection of laying hens. Retrieved from https://eurlex.europa.eu/legal-content/EN/TXT/HTML/?uri=LEGISSUM:112067\&from=EN

FAO. (2016). The state of food and agriculture: Climate change, agriculture and food security. Retrieved from http://www.fao.org/3/a-i6030e.pdf

FAO. (2017). Gateway to poultry production and products. Retrieved from http://www.fao.org/poultryproduction-products/production/en/

Gangnat, I. D. M., Mueller, S., Kreuzer, M., Messikommer, R. E., Siegrist, M., \& Visschers, V. H. M. (2018). Swiss consumers' willingness to pay and attitudes regarding dual-purpose poultry and eggs. Poultry Science, 97(3), 1089-1098. 
Geng, H., Song, H., Qi, J., \& Cui, D. (2011). Sustained release of VEGF from PLGA-nanoparticles embedded thermo-sensitive hydrogel in full-thickness porcine bladder acellular matrix. Nanoscale Research Letters, 312(6), 1-8.

Gerini, F., Alfnes, F., \& Schjøll, A. (2016). Organic- and Animal Welfare-labelled Eggs: Competing for the Same Consumers? Journal of Agricultural Economics, 67(2), 471-490.

Gracia, A., Barreiro-Hurlé, J., \& López-Galán, B. (2014). Are Local and Organic Claims Complements or Substitutes? A Consumer Preferences Study for Eggs. Journal of Agricultural Economics, 65(1), 49-67.

Grunert, K. G. (2005). Food quality and safety: Consumer perception and demand. European Review of Agricultural Economics, 32(3), 369-391.

Grunert, K. G., Hieke, S., \& Wills, J. (2014). Sustainability labels on food products: Consumer motivation, understanding and use. Food Policy, 44, 177-189.

Güney, O. I., \& Giraldo, L. (2019). Consumers' attitudes and willingness to pay for organic eggs: A discrete choice experiment study in Turkey. British Food Journal, 122(2), 678-692.

Heng, Y., Peterson, H. H., \& Li, X. (2013). Consumer attitudes toward farm-animal welfare: The case of laying hens. Journal of Agricultural and Resource Economics, 38(3), 418-434.

Hester, P. Y., \& Shea-Moore, M. (2005). Beak trimming egg-laying strains of chickens. World's Poultry Science Journal, 59(4), 458-474.

Karcher and Mench. (2018). Overview of commercial poultry production systems and their main welfare challenges. In Adance in poultry welfare.

Koch, G., \& Elbers, A. R. W. (2006). Outdoor ranging of poultry: A major risk factor for the introduction and development of High-Pathogenecity Avian Influenza. NJAS - Wageningen Journal of Life Sciences, 54(2), 179-194.

Köster, E. P. (2009). Diversity in the determinants of food choice: A psychological perspective. Food Quality and Preference, 20(2), 70-82.

Krautwald-Junghanns, M.-E., Cramer, K., Fischer, B., Förster, A., Galli, R., Kremer, F., ... Bartels, T. 
(2018). Current approaches to avoid the culling of day-old male chicks in the layer industry, with special reference to spectroscopic methods. Poultry Science, 97(3), 749-757.

Leinonen, I., Williams, A. G., Wiseman, J., Guy, J., \& Kyriazakis, I. (2012). Predicting the environmental impacts of chicken systems in the united kingdom through a life cycle assessment: Egg production systems. Poultry Science, 91(1), 26-40.

Lesnierowski, G., \& Stangierski, J. (2018). What's new in chicken egg research and technology for human health promotion? - A review. Trends in Food Science and Technology, 71(2017), 46-51.

Li, T., Bernard, J. C., Johnston, Z. A., Messer, K. D., \& Kaiser, H. M. (2017). Consumer preferences before and after a food safety scare: An experimental analysis of the 2010 egg recall. Food Policy, $66,25-34$.

Li, X., Li, H., Ma, W., Guo, Z., Li, X., Song, S., ... Zhang, Q. (2019). Development of precise GC-EIMS method to determine the residual fipronil and its metabolites in chicken egg. Food Chemistry, 281, 85-90.

Loh, W., \& Tang, M. L. K. (2018). The epidemiology of food allergy in the global context. International Journal of Environmental Research and Public Health, 2043(15), 1-8.

Lopez-Galan, B., Gracia, A., \& Barreiro-Hurle, J. (2013). What comes first, origin or production method? An investigation into the relative importance of different attributes in the demand for eggs. Spanish Journal of Agricultural Research, 11(2), 305-315.

Lu, Y., Cranfield, J., \& Widowski, T. (2013). Consumer Preference for Eggs from Enhanced Animal Welfare Production System: A Stated Choice Analysis. 2013 Annual Meeting, August 4-6, 2013, Washington, D.C.

Lusk, J. L. (2010). The effect of proposition 2 on the demand for eggs in California. Journal of Agricultural and Food Industrial Organization, 8(1).

Lusk, J. L. (2018). Consumer preferences for cage-free eggs and impacts of retailer pledges. Agribusiness, 35(2), 129-148.

Malone, T., \& Lusk, J. L. (2016). Putting the chicken before the egg price: An ex post analysis of 
California's battery cage ban. Journal of Agricultural and Resource Economics.

McNamara, D. J. (2015). The fifty year rehabilitation of the egg. Nutrients, 7(10), 8716-8722.

Mesías, F. J., Martínez-Carrasco, F., Martínez, J. M., \& Gaspar, P. (2011). Functional and organic eggs as an alternative to conventional production: A conjoint analysis of consumers' preferences. Journal of the Science of Food and Agriculture, 91(3), 532-538.

Montossi, F., Cazzuli, F., Brito, G., Realini, C., Luzardo, S., Rovira, P., \& Font-I-Furnols, M. (2018). The challenges of aligning consumer preferences and production systems: Analysing the case of a small beef meat exporting country. International Journal of Agricultural Policy and Research, 6(9), 144-159.

Napolitano, F., Girolami, A., \& Braghieri, A. (2010). Consumer liking and willingness to pay for high welfare animal-based products. Trends in Food Science \& Technology, 21(11), 537-543.

Ngapo, T. M., Braña Varela, D., \& Rubio Lozano, M. S. (2017). Mexican consumers at the point of meat purchase. Beef choice. Meat Science, 134, 34-43.

Norwood, F. B., \& Lusk, J. L. (2011a). A calibrated auction-conjoint valuation method: Valuing pork and eggs produced under differing animal welfare conditions. Journal of Environmental Economics and Management, 62(1), 80-94.

Norwood, F. B., \& Lusk, J. L. (2011b). Compassion, by the Pound: The Economics of Farm Animal Welfare. In Compassion, by the Pound: The Economics of Farm Animal Welfare.

Ochs, D. S., Wolf, C. A., Widmar, N. J. O., \& Bir, C. (2018). Consumer perceptions of egg-laying hen housing systems. Poultry Science, 97(5), 1848-1851.

Ochs, Wolf, C. A., Widmar, N. O., Bir, C., \& Lai, J. (2019). Hen housing system information effects on U.S. egg demand. Food Policy, 87(10), 101743.

Parisi, M. A., Northcutt, J. K., Smith, D. P., Steinberg, E. L., \& Dawson, P. L. (2015). Microbiological contamination of shell eggs produced in conventional and free-range housing systems. Food Control, 47, 161-165.

Pelletier, N. (2017). Life cycle assessment of Canadian egg products, with differentiation by hen 
housing system type. Journal of Cleaner Production, 152, 167-180.

Pettersson, I. C., Weeks, C. A., Wilson, L. R. M., \& Nicol, C. J. (2016). Consumer perceptions of freerange laying hen welfare. British Food Journal, 118(8), 1999-2013.

$\begin{array}{llllll}\text { Proposition } & 2 . & \text { (2008). } & \text { Proposition } & \text { 2. } & \text { Retrieved }\end{array}$ https://web.archive.org/web/20090410080219/http://voterguide.sos.ca.gov/past/2008/general/titl e-sum/prop2-title-sum.htm

Rahmani, D., Kallas, Z., Pappa, M., \& Gil, J. M. (2019). Are Consumers’ Egg Preferences Influenced by Animal-Welfare Conditions and Environmental Impacts? Sustainability, 11(22), 6218.

Rodenburg, T. B., Tuyttens, F. A. M., de Reu, K., Herman, L., Zoons, J., \& Sonck, B. (2008). Welfare assessment of laying hens in furnished cages and non-cage systems: Assimilating expert opinion. Animal Welfare, 17(4), 355-361.

Sass, C. A. B., Kuriya, S., Da Silva, G. V., Silva, H. L. A., Da Cruz, A. G., Esmerino, E. A., \& Freitas, M. Q. (2018). Completion task to uncover consumer's perception: A case study using distinct types of hen's eggs. Poultry Science, 97(5), 2591-2598.

Spain, C. V., Freund, D., Mohan-Gibbons, H., Meadow, R. G., \& Beacham, L. (2018). Are they buying it? United states consumers' changing attitudes toward more humanely raised meat, eggs, and dairy. Animals, 128(8), 1-14.

Surai, P. F., \& Sparks, N. H. C. (2001). Designer eggs: From improvement of egg composition to functional food. Trends in Food Science and Technology, 12(1), 7-16.

Teixeira, D. L., Larraín, R., \& Hötzel, M. J. (2018). Are views towards egg farming associated with Brazilian and Chilean egg consumers' purchasing habits? PLoS ONE, 13(9), 1-16.

Tran, H. T., Ferrell, W., \& Butt, T. R. (2010). An estrogen sensor for poultry sex sorting. Journal of Animal Science, 88(4), 1358-1364.

UEP. (2017). Guidelines for cage and cage-free housing. Retrieved from https://uepcertified.com/wpcontent/uploads/2015/08/UEP-Animal-Welfare-Guidelines-20141.pdf

Vanhonacker, F., van Poucke, E., Tuyttens, F., \& Verbeke, W. (2010). Citizens' Views on Farm 
Animal Welfare and Related Information Provision: Exploratory Insights from Flanders, Belgium. Journal of Agricultural and Environmental Ethics, 116(1), 11-20.

Vecchio, R., \& Annunziata, A. (2012). Italian consumer awareness of layer hens' welfare standards: A cluster analysis. International Journal of Consumer Studies, 36(6), 647-655.

Wardy, W., Sae-Eaw, A., Sriwattana, S., No, H. K., \& Prinyawiwatkul, W. (2015). Assessing Consumer Emotional Responses in the Presence and Absence of Critical Quality Attributes: A Case Study with Chicken Eggs. Journal of Food Science, 80(7), 1-7.

Weissmann, A., Reitemeier, S., Hahn, A., Gottschalk, J., \& Einspanier, A. (2013). Sexing domestic chicken before hatch: A new method for in ovo gender identification. Theriogenology, 80(3), 199205.

Whiley, H., \& Ross, K. (2015). Salmonella and eggs: From production to plate. International Journal of Environmental Research and Public Health, 12(3), 2543-2556.

Yang, Y. C. (2018). Factors affecting consumers' willingness to pay for animal welfare eggs in Taiwan. International Food and Agribusiness Management Review, 21(6), 741-754.

Zakowska-Biemans, S., \& Tekień, A. (2017). Free range, organic? Polish consumers preferences regarding information on farming system and nutritional enhancement of eggs: A discrete choice based experiment. Sustainability, 9(11), 1-16.

Zhu, Y., Vanga, S. K., Wang, J., \& Raghavan, V. (2018). Impact of food processing on the structural and allergenic properties of egg white. Trends in Food Science and Technology, 78(May), 188196. 


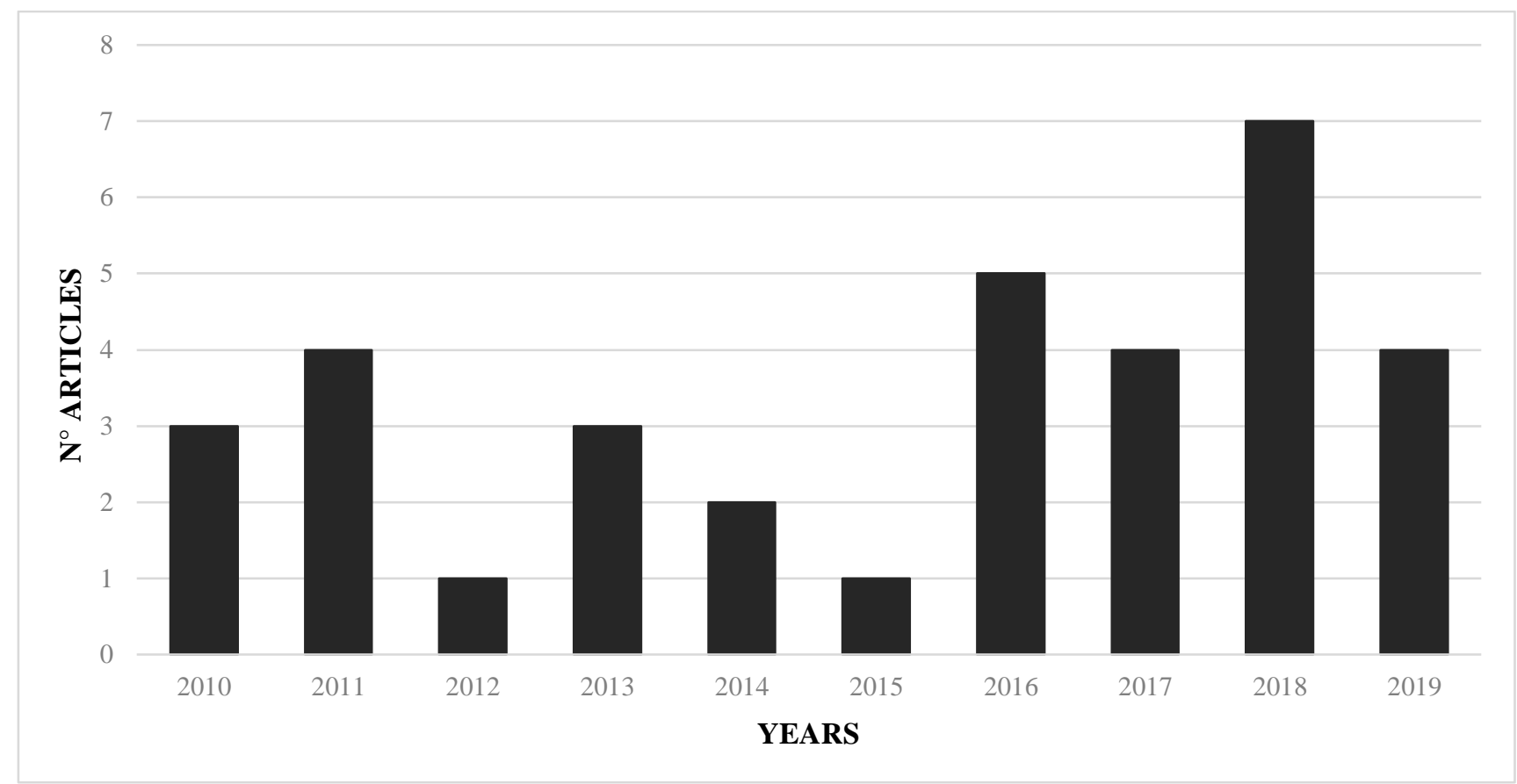

Fig. 1 - Number of research articles included in the topic of consumer research on eggs from Scopus, Science Direct, AgEcon Search, and Web of Science databases at 31.12.2019 (search terms: "eggs", AND “consumers" AND "preferences", OR "attitude", OR "perception", OR "choice", OR "behaviour", OR "purchase intention", OR "willingness to pay"). 


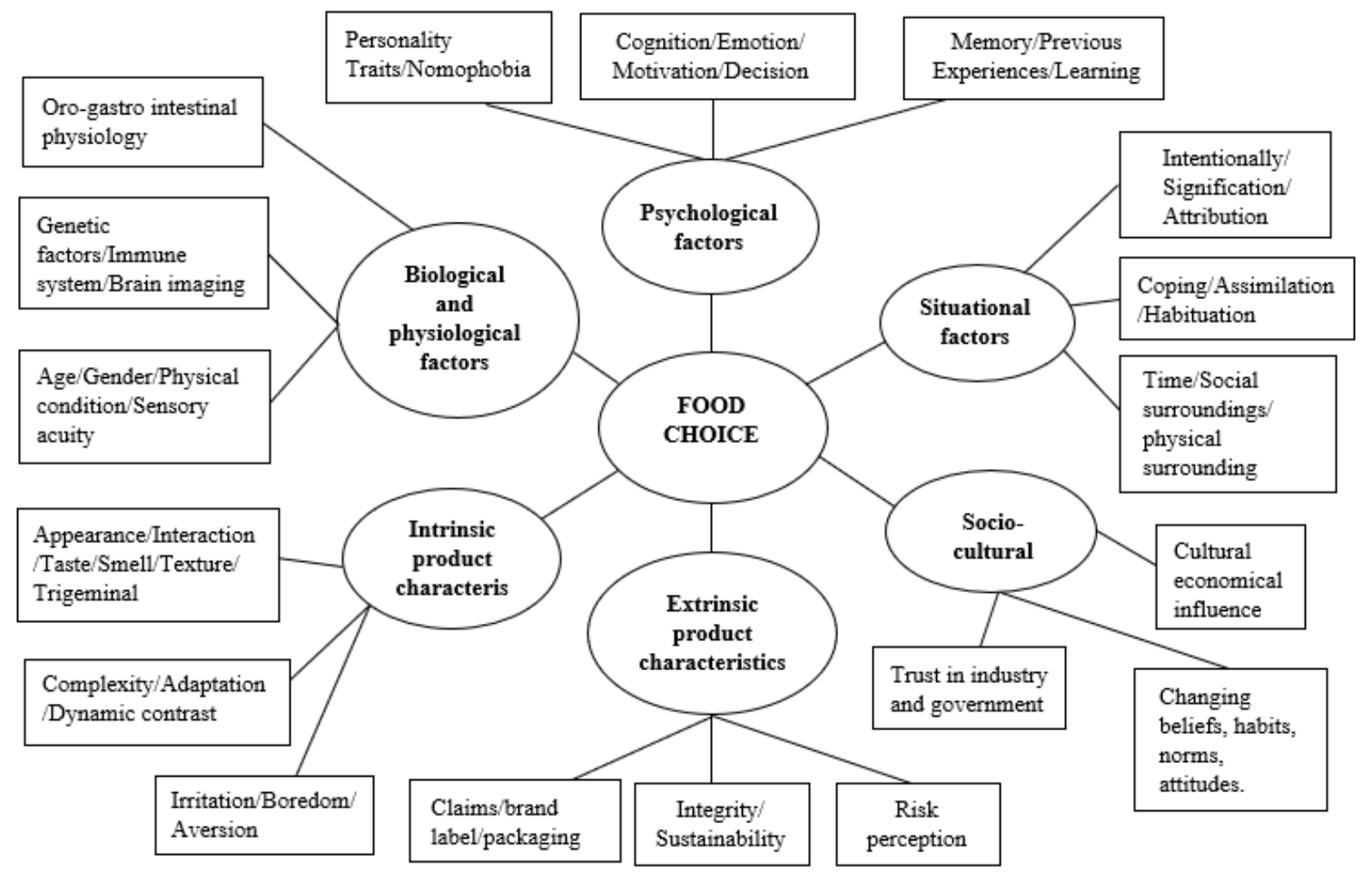

Fig. 2 - Essential factors and sub-factors that influence eating and drinking behaviour and food choice (Source: Köster, 2009). 


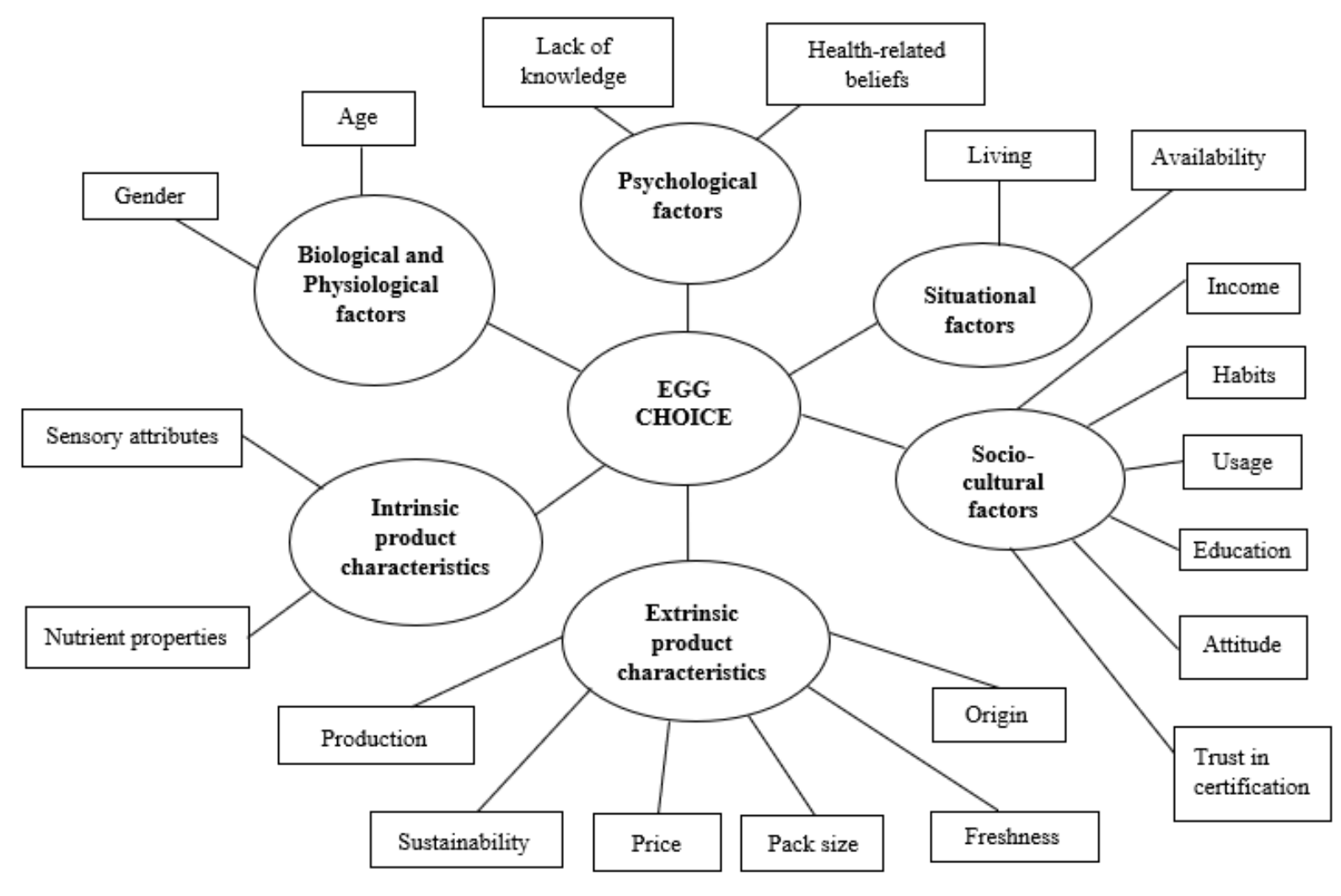

Fig. 3 - Essential factors and sub-factors that drive consumer behaviour, perceptions, and preferences for eggs, adapted from Mojet's model. Sub-factors were identified from the literature review of the 34 articles. 
APPENDIX A

Table A1 - Overview of the selected articles ( $n=34)$ about consumer behaviour, perceptions, and preferences towards eggs.

\begin{tabular}{|c|c|c|c|c|c|}
\hline NO. & AUTHORS & $\begin{array}{l}\text { COUNTRY OF } \\
\text { INVESTIGATION }\end{array}$ & METHODOLOGY & SAMPLE SIZE & FINDINGS \\
\hline 1 & $\begin{array}{c}\text { Allender \& } \\
\text { Richards (2010) }\end{array}$ & Canada & $\begin{array}{c}\text { Quantitative } \\
\text { (Choice Experiment) }\end{array}$ & 2,000 & $\begin{array}{l}\text { - Consumers were unwilling to pay a premium price for cage-free eggs, } \\
\text { particularly those from larger households and/or households with lower } \\
\text { income. }\end{array}$ \\
\hline 2 & $\begin{array}{l}\text { Ahmad Hanis et } \\
\text { al. (2013) }\end{array}$ & Malaysia & $\begin{array}{l}\text { Quantitative } \\
\text { (Conjoint analysis) } \\
\text { and qualitative } \\
\text { (Focus groups) }\end{array}$ & $\begin{array}{l}202 \text { for the } \\
\text { conjoint analysis } \\
33 \text { for the focus } \\
\text { groups }\end{array}$ & $\begin{array}{l}\text { - Consumers were willing to pay a premium price for eggs of large size, } \\
\text { enriched with omega 3, of brown eggshell, and packaged in boxes of ten } \\
\text { eggs per pack. }\end{array}$ \\
\hline 3 & $\begin{array}{l}\text { Al-Ajeeli et al. } \\
\qquad(2018)\end{array}$ & United States & $\begin{array}{l}\text { Sensory consumer } \\
\text { test }\end{array}$ & 60 & $\begin{array}{l}\text { - Consumers preferred the texture of scrambled eggs from hens fed with } \\
\text { soybean-free diet than for scrambled eggs from hens fed with soybean } \\
\text { meal diet. } \\
\text { - Consumers preferred the flavour of the hard-cooked eggs from the caged } \\
\text { system than from the free-range system. }\end{array}$ \\
\hline 4 & Andersen, (2011) & Denmark & $\begin{array}{c}\text { Quantitative } \\
\text { (Choice experiment) }\end{array}$ & 2,000 & $\begin{array}{l}\text { - Consumers were willing to pay a premium price for increasing animal } \\
\text { welfare standards in egg production. } \\
\text { - Consumers' willingness to pay for organic eggs was higher than it was } \\
\text { for barn and free-range eggs. }\end{array}$ \\
\hline 5 & $\begin{array}{c}\text { Ayim-Akonor and } \\
\text { Akonor (2014) }\end{array}$ & Ghana & $\begin{array}{l}\text { Quantitative } \\
\text { (Self-administered } \\
\text { questionnaire) }\end{array}$ & 448 & $\begin{array}{l}\text { - Consumers showed higher preferences for eggs from locally raised hens } \\
\text { than free-range eggs, large sized, brown eggshell, and deep yellow yolk. } \\
\text { - Most consumers believed that consuming eggs would increase } \\
\text { cholesterol in the blood. }\end{array}$ \\
\hline 6 & $\begin{array}{l}\text { Baba, Kallas and } \\
\text { Realini (2017) }\end{array}$ & Spain & $\begin{array}{l}\text { Quantitative } \\
\text { (Analytical hierarchy } \\
\text { process AHP) }\end{array}$ & 122 & $\begin{array}{l}\text { - Compared to free-range eggs, omega-3-enriched eggs had lower flavour } \\
\text { acceptance, as well as higher yolk-colour and odour acceptance. } \\
\text { Consumers gave more importance to cage-free production and price of } \\
\text { eggs followed by the origin and egg size. }\end{array}$ \\
\hline
\end{tabular}




\begin{tabular}{|c|c|c|c|c|c|}
\hline 7 & $\begin{array}{l}\text { Bejaei, Wiseman, } \\
\& \text { Cheng (2011) }\end{array}$ & Canada & $\begin{array}{c}\text { Quantitative } \\
\text { (Questionnaire) }\end{array}$ & 1,027 & $\begin{array}{l}\text { - Free-range egg consumers came from smaller households and had a } \\
\text { higher education level and income than white- and caged-egg } \\
\text { consumers. } \\
\text { - Price was the most important attribute for consumers when purchasing } \\
\text { eggs. }\end{array}$ \\
\hline 8 & $\begin{array}{l}\text { Bennett et al. } \\
\quad \text { (2016) }\end{array}$ & United Kingdom & $\begin{array}{l}\text { Qualitative } \\
\text { (Focus groups) and } \\
\text { quantitative } \\
\text { (Online } \\
\text { questionnaire) }\end{array}$ & $\begin{array}{l}40 \text { for focus } \\
\text { groups and } 1,776 \\
\text { for online } \\
\text { questionnaire }\end{array}$ & $\begin{array}{l}\text { - While consumers had a very positive attitude towards free-range eggs, } \\
\text { they were especially uninformed about some aspects of free-range egg } \\
\text { production, such as the injurious pecking. }\end{array}$ \\
\hline 9 & $\begin{array}{l}\text { Bray and Ankeny } \\
\text { (2017) }\end{array}$ & Australia & $\begin{array}{c}\text { Qualitative } \\
\text { (Focus groups) }\end{array}$ & 73 & $\begin{array}{l}\text { - Free-range and cage-free eggs were perceived to have higher quality, } \\
\text { nutrition, and safety and better sensory characteristics than caged eggs. } \\
\text { - Free-range egg purchasing was more often associated with the } \\
\text { willingness to avoid "industrialized" eggs than of the valuing of hens' } \\
\text { animal welfare. }\end{array}$ \\
\hline 10 & $\begin{array}{l}\text { Chang, Lusk and } \\
\text { Norwood (2010) }\end{array}$ & United States & $\begin{array}{l}\text { Quantitative } \\
\text { (Analysis of point of } \\
\text { sales scanner data } \\
\text { from } 2007 \text { to 2009) }\end{array}$ & - & $\begin{array}{l}\text { - A significant premium price was paid for cage-free eggs. However, } \\
\text { about } 42 \% \text { of the typically observed premium for cage-free eggs was } \\
\text { attributable to egg colour rather than differences in hens' living } \\
\text { conditions. }\end{array}$ \\
\hline 11 & $\begin{array}{l}\text { Doyon et al, } \\
\quad(2016)\end{array}$ & Canada & $\begin{array}{c}\text { Quantitative } \\
\text { (Choice experiment) }\end{array}$ & 572 & $\begin{array}{l}\text { - Consumers were willing to pay more for cage-free eggs but not for } \\
\text { enriching cage space or adding scratch pads and dust baths. }\end{array}$ \\
\hline 12 & $\begin{array}{l}\text { Gangnat } e t \text { al. } \\
\quad \text { (2018) }\end{array}$ & Switzerland & $\begin{array}{c}\text { Quantitative } \\
\text { (Choice experiment) }\end{array}$ & 402 & $\begin{array}{l}\text { - Consumers' knowledge about poultry production was low. } \\
\text { - The dual-purpose poultry alternative was preferred to chick culling, but } \\
\text { no preference emerged between dual-purpose poultry and in-ovo } \\
\text { sexing. } \\
\text { - Consumers' willingness to pay for dual-purpose poultry was lower for } \\
\text { chickens than eggs. }\end{array}$ \\
\hline 13 & $\begin{array}{l}\text { Gerini, Alfnes and } \\
\text { Schjøll (2016) }\end{array}$ & Norway & $\begin{array}{c}\text { Quantitative } \\
\text { (Choice experiment) }\end{array}$ & 900 & $\begin{array}{l}\text { - Consumers purchasing organic food more often were also willing to } \\
\text { pay more for organic eggs than cage-free eggs. } \\
\text { - Consumers who occasionally purchase organic products were } \\
\text { unwilling to pay more for organic eggs than for cage-free eggs. } \\
\text { - A segment of consumers avoiding organic eggs, even when they cost } \\
\text { the same as other eggs, was also found. }\end{array}$ \\
\hline
\end{tabular}




\begin{tabular}{|c|c|c|c|c|c|}
\hline 14 & $\begin{array}{l}\text { Gracia, Barreiro- } \\
\text { Hurlé and López- } \\
\text { Galán (2014) }\end{array}$ & Spain & Choice experiment & 400 & $\begin{array}{l}\text { - Consumers were found to be willing to pay higher prices for barn, free- } \\
\text { range, and/or organic eggs instead of caged eggs as well as for local, } \\
\text { regional, and national eggs over imported eggs. }\end{array}$ \\
\hline 15 & Guney (2019) & Turkey & $\begin{array}{c}\text { Quantitative } \\
\text { (Choice experiment) }\end{array}$ & 552 & $\begin{array}{l}\text { - Consumers perceived organic eggs to be healthful, nutritious, and } \\
\text { delicious. } \\
\text { - Also, individual benefits had greater relevance than collectivist } \\
\text { benefits on the consumer choice to purchase organic eggs. }\end{array}$ \\
\hline 16 & $\begin{array}{l}\text { Heng, Peterson } \\
\text { and } \operatorname{Li}(2013)\end{array}$ & United States & $\begin{array}{c}\text { Quantitative } \\
\text { (Choice experiment) }\end{array}$ & 449 & $\begin{array}{l}\text { - Consumers perceived caged-egg systems as reducing hens' welfare and } \\
\text { were willing to pay a premium price for eggs produced in cage-free egg } \\
\text { systems. }\end{array}$ \\
\hline 17 & Li et al. (2017) & United States & $\begin{array}{l}\text { Two experiments (A } \\
\text { first and a second } \\
\text { follow-up of the first) }\end{array}$ & $\begin{array}{l}117 \text { in the first } \\
\text { and } 74 \text { in the } \\
\text { second } \\
\text { experiment }\end{array}$ & $\begin{array}{l}\text { - Consumers' willingness to pay for organic eggs increased after the } \\
2010 \text { recall caused by a salmonella outbreak in the US. }\end{array}$ \\
\hline 18 & $\begin{array}{l}\text { Lopez-Galan, } \\
\text { Gracia and } \\
\text { Barreiro-Hurle } \\
\quad(2013)\end{array}$ & Spain & $\begin{array}{c}\text { Quantitative } \\
\text { (Choice experiment) }\end{array}$ & 803 & $\begin{array}{l}\text { - Consumers were willing to pay higher prices for packages of six free- } \\
\text { range and organic eggs than for bigger packages of free-range eggs. }\end{array}$ \\
\hline 19 & $\begin{array}{l}\text { Lu, Cranfield and } \\
\text { Widowski (2013) }\end{array}$ & United States & $\begin{array}{c}\text { Quantitative } \\
\text { (Choice experiment) }\end{array}$ & 750 & $\begin{array}{l}\text { - Consumers were willing to pay a premium for free-range eggs, but not } \\
\text { for caged eggs. } \\
\text { - A positive, marginal willingness to pay emerged for cage-free systems, } \\
\text { outdoor access, and access to nest boxes, perches, and scratching pads. }\end{array}$ \\
\hline 20 & Lusk (2010) & United States & $\begin{array}{l}\text { Quantitative (Retailer } \\
\text { scanner data from } \\
2005 \text { to 2009) }\end{array}$ & - & $\begin{array}{l}\text { - After the approval of Proposition } 2 \text { in California, demand for cage-free } \\
\text { and organic eggs increased over time, whereas demand for caged eggs } \\
\text { fell. }\end{array}$ \\
\hline 21 & Lusk (2018) & United States & $\begin{array}{c}\text { Quantitative } \\
\text { (Choice experiments) }\end{array}$ & 2,000 & $\begin{array}{l}\text { - Potential for an increasing market-share for cage-free eggs emerged, } \\
\text { however, it will likely remain a niche market. }\end{array}$ \\
\hline 22 & $\begin{array}{l}\text { Mesías et al. } \\
\quad(2011)\end{array}$ & Spain & $\begin{array}{c}\text { Quantitative } \\
\text { (Conjoint analysis) }\end{array}$ & 361 & $\begin{array}{l}\text { - Price was found to be the most important attribute determining } \\
\text { consumer preferences, followed by rearing conditions. }\end{array}$ \\
\hline
\end{tabular}




\begin{tabular}{|c|c|c|c|c|c|}
\hline 23 & $\begin{array}{l}\text { Norwood and } \\
\text { Lusk (2011) }\end{array}$ & United States & $\begin{array}{l}\text { Quantitative } \\
\text { (Calibrated auction- } \\
\text { conjoint method } \\
\text { CACM) }\end{array}$ & 291 & $\begin{array}{l}\text { - Consumers were willing to pay higher prices for a dozen eggs raised in } \\
\text { an aviary and pasture system than for eggs raised in cage systems. }\end{array}$ \\
\hline 24 & Ochs et al. (2018) & United States & $\begin{array}{l}\text { Quantitative } \\
\text { (Online survey) }\end{array}$ & 2,813 & $\begin{array}{l}\text { - Consumers perceived cage-free aviaries and free-range systems as } \\
\text { achieving the same positive impact on hen health and stress as well as } \\
\text { the environment compared to caged-egg systems. }\end{array}$ \\
\hline 25 & Ochs et al., (2019) & United States & $\begin{array}{c}\text { Quantitative } \\
\text { (Choice experiment) }\end{array}$ & 2,813 & $\begin{array}{l}\text { - When respondents were shown videos of egg production systems, they } \\
\text { were not able to differentiate between a cage-free aviary and enriched } \\
\text { colony housings, whereas with no video information willingness to pay } \\
\text { was higher for cage-free systems. }\end{array}$ \\
\hline 26 & $\begin{array}{l}\text { Pettersson et al. } \\
\quad \text { (2016) }\end{array}$ & United Kingdom & $\begin{array}{l}\text { Quantitative } \\
\text { (Questionnaire) }\end{array}$ & 6,378 & $\begin{array}{l}\text { - Consumers preferred free-range eggs because hens were believed to be } \\
\text { "happier" and "healthier" and eggs were perceived to taste better. } \\
\text { - Compared to animal welfare specialists, respondents differed in their } \\
\text { views on factors contributing to hen welfare, but their views on } \\
\text { resource suitability were similar. }\end{array}$ \\
\hline 27 & $\begin{array}{l}\text { Rahmani et al. } \\
\text { (2019) }\end{array}$ & Spain & $\begin{array}{c}\text { Quantitative } \\
\text { (Choice experiment) }\end{array}$ & 520 & $\begin{array}{l}\text { - Consumers were willing to pay higher prices for free-range eggs, but } \\
\text { not for organic eggs. } \\
\text { - Consumer were willing to pay higher prices for reducing GHG } \\
\text { emissions and water use. }\end{array}$ \\
\hline 28 & Sass et al. (2018) & Brazil & $\begin{array}{l}\text { Qualitative } \\
\text { (Completion task } \\
\text { technique) }\end{array}$ & 100 & $\begin{array}{l}\text { - "Health" and "price" emerged as positive factors that drive egg } \\
\text { purchasing and consumption. }\end{array}$ \\
\hline 29 & Spain et al. (2018) & United States & $\begin{array}{l}\text { Quantitative } \\
\text { (Online survey) }\end{array}$ & 1,000 & $\begin{array}{l}\text { - Most consumers showed interest for labels providing information on } \\
\text { how hens were raised and believed there should be an objective third } \\
\text { party to ensure farm animal welfare reliability. }\end{array}$ \\
\hline 30 & $\begin{array}{c}\text { Teixeira, Larraín } \\
\text { and Hötzel (2018) }\end{array}$ & Brazil and Chile & $\begin{array}{l}\text { Quantitative } \\
\text { (Online survey) }\end{array}$ & $\begin{array}{l}358 \text { Brazilian } \\
\text { and } 358 \text { Chilean }\end{array}$ & $\begin{array}{l}\text { - Consumers were concerned about animal welfare, naturalness, } \\
\text { hygiene, production, and ethical aspects of egg production, which } \\
\text { many associated with improved health, sensory, and nutritional quality } \\
\text { of the eggs. }\end{array}$ \\
\hline 31 & $\begin{array}{c}\text { Vecchio and } \\
\text { Annunziata (2012) }\end{array}$ & Italy & $\begin{array}{l}\text { Quantitative } \\
\text { (Online survey) }\end{array}$ & 300 & $\begin{array}{l}\text { - Consumers were unaware of the current mandatory labelling system } \\
\text { for eggs. }\end{array}$ \\
\hline
\end{tabular}




\begin{tabular}{|c|c|c|c|c|c|}
\hline 32 & $\begin{array}{l}\text { Wardy et al. } \\
\quad(2015)\end{array}$ & United States & $\begin{array}{c}\text { Quantitative } \\
\text { (Online survey) }\end{array}$ & 320 & $\begin{array}{l}\text { - Consumers valued freshness and appearance, such as the absence of } \\
\text { visible cracks on the eggshell. }\end{array}$ \\
\hline 33 & Yang, Y. (2018) & Taiwan & $\begin{array}{l}\text { Quantitative } \\
\text { (Online survey) }\end{array}$ & 322 & $\begin{array}{l}\text { - Consumers showed awareness about the different types of production } \\
\text { methods such as battery cages, free range etc. } \\
\text { - Older and higher-income consumers were willing to pay higher prices } \\
\text { for barn and free-range eggs than younger and lower-income } \\
\text { consumers. } \\
\text { - Buddhists and Taoists were willing to pay more than those who were } \\
\text { not. } \\
\text { - Consumers were willing to pay higher prices for cage-free eggs } \\
\text { because they were perceived to be safer. }\end{array}$ \\
\hline 34 & $\begin{array}{l}\text { Zakowska- } \\
\text { Biemans and } \\
\text { Tekień (2017) }\end{array}$ & Poland & $\begin{array}{c}\text { Quantitative } \\
\text { (Choice experiment) }\end{array}$ & 935 & $\begin{array}{l}\text { - Price and production method were the factors that more significantly } \\
\text { affected consumer preferences, while nutrition and health claims, egg } \\
\text { size, package size, and hen breed were far less important. }\end{array}$ \\
\hline
\end{tabular}

